\title{
Multiscale approach of fish responses to different types of environmental contaminations: A case study
}

\author{
Nicolas Mayon $^{\mathrm{a}}$, Arnaud Bertrand ${ }^{\mathrm{b}}$, Delphine Leroy ${ }^{\mathrm{c}}$, Christelle Malbrouck ${ }^{\mathrm{a}}$, \\ S.N.M. Mandiki ${ }^{\mathrm{a}}$, Frédéric Silvestre ${ }^{\mathrm{a}}$, Anne Goffart ${ }^{\mathrm{b}}$, \\ Jean-Pierre Thomé ${ }^{\mathrm{b}, \mathrm{c}}$, Patrick Kestemont ${ }^{\mathrm{a}, *}$ \\ a Unité de Recherches en Biologie des Organismes (URBO), Facultés Universitaires N.D. de la Paix, Namur, Belgium \\ b Aquapôle, Université de Liège, Belgium \\ ${ }^{\mathrm{c}}$ Laboratoire d'Ecologie Animale et Ecotoxicologie (LEAE), Université de Liège, Belgium
}

Received 22 June 2005; received in revised form 28 February 2006; accepted 6 March 2006

Available online 5 June 2006

\begin{abstract}
In order to study the responses of wild fish to environmental contaminations, different sites (two references and three contaminated) were sampled across the Walloon hydrographical network (southern Belgium). The status of fish communities was characterized according to an index of biotic integrity (IBI). Furthermore, population structure, reproductive parameters and biochemical assays were performed on chub (Leuciscus cephalus) as sentinel species. The results showed impaired responses in fish sampled downstream paper mill effluents (BKME), in a polychlorinated biphenyls (PCB) contaminated site, and in a river receiving pesticides (i.e. atrazine and hexachlorocyclohexane). High level of hepatic 7-ethoxyresorufin-Odeethylase (EROD) activity were evidence of direct toxicant exposure, while population structures showed unbalanced size-frequency distributions. Moreover, in the pesticide contaminated site, a higher proportion of atretic oocytes was found in females and abnormally high plasma alkali-labile phosphorus (ALP) values were noticed in males, compared to reference sites, suggesting that chubs were exposed to estrogenic compounds. IBI scores from both sites were also lower than in reference sites. On the other hand, no particular response was found in hepatic glutathione-S-transferase (GST) activities, hepatic heat-shock protein HSP70 concentrations and plasma sex steroids (estradiol-17 $\beta$, 11-ketotestosterone and testosterone) in chubs from any sites. By using a multiparametric approach, a better understanding of response mechanisms to pollution in fish may be achieved in order to improve the ecological status of river ecosystems.
\end{abstract}

(C) 2006 Elsevier B.V. All rights reserved.

Keywords: Biomarkers; Bioindicators; Multiscale study; Organization levels; Leuciscus cephalus; Chub

\footnotetext{
* Corresponding author. Unité de Recherches en Biologie des Organismes, (URBO), Facultés Universitaires Notre-Dame de la Paix, Rue de Bruxelles, 61, B-5000, Namur, Belgium. Tel.: +32 817243 63; fax: +3281724362 .

E-mail address: patrick.kestemont@fundp.ac.be (P. Kestemont).
}

\section{Introduction}

Following the increase in human activities since the early twentieth century, the environment is subjected to relentless contaminations produced by industry, intensive agriculture or urbanization. As a key constitutive element of ecosystems, water have become the final receptacle for a variety of xenobiotics such as 
polychlorinated biphenyls (PCB), pesticides and more complex wastes such as sewage treatment work effluents (STW effluents) or bleached kraft mill effluents (BKME).

Such pollutants can induce various biological responses in fish, affecting the organisms from the biochemical to the population-community levels (Hugla et al., 1995; Kovacs et al., 2002; Porter and Janz, 2003; Eder et al., 2004). During the last twenty years, a large body of biomonitoring data has been accumulated in order to assess whether lower level responses could be used as indicators to determine toxic effect of xenobiotics (Triebskorn et al., 2001). Biomarkers were then defined as measurable modifications at the molecular, biochemical, cellular, physiological or behavioural levels revealing the exposure of an organism to xenobiotics (Lagadic et al., 1997). In fish, detoxification enzymes (Hugla et al., 1995; van der Oost et al., 1998), stress proteins (Janz et al., 2001; Weber et al., 2002), steroid hormone levels (Monteiro et al., 2000; Sepúlveda et al., 2002; Spanò et al., 2004), histological alterations (Thomé et al., 1993; Bernet et al., 1999; Gernöfer et al., 2001) and numerous other parameters have been widely used in field biomonitoring studies as well as in laboratory investigations. Although the impacts of environmental contaminants have been well documented in fish at the molecular, cellular, organ and whole organism levels, few studies have focused on the higher levels of organization (Siligato and Böhmer, 2001, 2002). However, when confronted with the huge ecosystem complexity, single-level approaches are often of limited use to assess the health status of the environment (Adams et al., 1992a) and extrapolations have to be made over a range of organization levels (Adams et al., 2000; Bernet et al., 2000). While it is not surprising that contaminated organisms display molecular and biochemical responses, it is difficult to establish that higher organization levels are actually affected by the pollution (van der Oost et al., 2003). On the other hand, investigations at the upper levels of organization do not allow a complete understanding of the underlying mechanisms responsible for the observed disruption (Attrill and Depledge, 1997). Additional intermediatelevel effects occurring between the short-term early warning responses and the more ecologically relevant changes at the population or community levels must also be examined to give a realistic view of the ecological health status of a given ecosystem.

The IBI analysis (Karr et al., 1986), modified to cope with the particularities of European fish assemblages (Kestemont et al., 2000), was used to assess the effects of pollution on fish communities. Other levels of organi- zation were investigated in chub (Leuciscus cephalus) as a sentinel species (Vindimian et al., 1991; Devaux et al., 1998; Flammarion et al., 2002). This species was selected because of its wide distribution across the studied area, its tolerance to water pollution and its large size ensuring the necessary supply of biological material for assays. The juvenile/adult ratio was examined at the population level, as pollutant exposure may result in disrupted age-frequency distributions in fish (Adams et al., 1992a; Siligato and Böhmer, 2001).

Reproduction is a fundamental process in the dynamic of a population. Even a slight chronic stress can affect reproduction and trigger a population decline (Power, 1997). Several xenobiotics are known to affect the reproductive function in various organisms (Arukwe, 2001). For that reason, it appeared interesting to investigate the responses of reproductive parameters as intermediate-level effects. In fish, hormones play an essential role in gonadal development, and display specific seasonal cycles. It is now well established that some anthropogenic chemicals can disrupt the endocrine systems of wildlife species (Kime, 1998). Therefore, the effects of xenobiotics on fish reproduction can be detected using plasma steroid hormone assays. Altered plasma sex steroid concentrations, including testosterone $(\mathrm{T})$, estradiol-17 $\beta$ (E2), and 11-ketotestosterone (11-KT), were noted in different fish species living in variously contaminated sites (McMaster et al., 1995; Janssen et al., 1997; Sepúlveda et al., 2002). The sex steroid estradiol-17 $\beta$ activates the production of vitellogenin by the liver. This protein is then incorporated into maturing oocytes (Kime, 1998). Vitellogenin synthesis takes place only in females, but it is possible to induce it in males by exposing them to estrogens or estrogenically active chemicals. Therefore, vitellogenin induction in males has been shown to be a specific biomarker for exposure to endocrine disrupting chemicals (Wahli et al., 1998; Kime et al., 1999). Finally, the structural integrity of gonads can be altered by xenobiotics. Most studies show a decrease in the gonadosomatic index (GSI) in contaminated fish (Kime, 1998), as noted by Janz et al. (2001) in white suckers (Catostomus commersonii) living downstream of a paper mill. Abnormal gonadal development like delayed maturation, high levels of atresia or intersexuality may also be detected by histological analysis. Such parameters are frequently investigated in fish exposed to anthropogenic chemicals or living in contaminated environments (Jobling et al., 1998; Bateman et al., 2004; Spanò et al., 2004).

The detoxification and excretion of a xenobiotic often requires its biotransformation into a more hydrosoluble 
metabolite, either by oxidation (phase one), coupling with an endogenous molecule (phase two) or both processes occurring successively (Monod, 1997). Therefore, biochemical measurements were also carried out as hepatic ethoxyresorufin-Odeethylase (EROD) and glutathione-S-transferase (GST) activity, which are detoxification enzymes, phase one and phase two, respectively (Pickering and Pottinger, 1995; Lawrence et al., 2003). The stress induced by pollutants may also affect proteins and cause damages to the cells. Heatshock proteins (HSP) are molecular chaperones binding to intracellular proteins to maintain their native conformation and avoid the accumulation of toxic aggregates in the cell (Feder and Hofmann, 1999). Therefore, hepatic levels of the $70-\mathrm{kDa}$ stress protein (HSP70) can be used as a biomarker in the monitoring of environmental contaminations (Dhainaut et al., 1997).

By using a multiparametric approach of environmental effects of xenobiotics, a better understanding of response mechanisms to pollution in fish may be achieved in order to improve the ecological status of river ecosystems. The aim of this study was therefore to find out whether the impacts of different contaminations could be observed at multiple levels of biological organization in fish.

\section{Material and methods}

\subsection{Site selection}

Sampling sites were selected in order to evaluate the effects of different types of deterioration on physiological responses as well as on population and community assemblages of fish. Two sampling sites were considered as reference sites while 3 sites were considered as deteriorated, due to a contamination by different chemicals (Fig. 1). The selection of reference sites was based on the procedure dictated by the European Water Framework Directive (Council of European Communities, 2000). In this procedure, anthropogenic impacts are defined for five criteria (hydrological regime, river connectivity, morphological conditions, toxic acidification and nutrient organic inputs) which are coded by expertise or based on existing datasets from 1 (no impact) to 5 (high impact). Only sites with impact classes 1 and 2 for all criteria can be retained as reference sites. This was the case for the Semois and Ourthe Rivers, both tributaries of the Meuse River, at the stations Chiny and Maboge, respectively. The station of Lamorteau, located in the Ton River downstream a paper mill (Burgo-Ardennes), is contaminated by bleached kraft mill effluents (BKME). The station Vaux-sous-Chêvremont, located in the Vesdre River, was selected because of

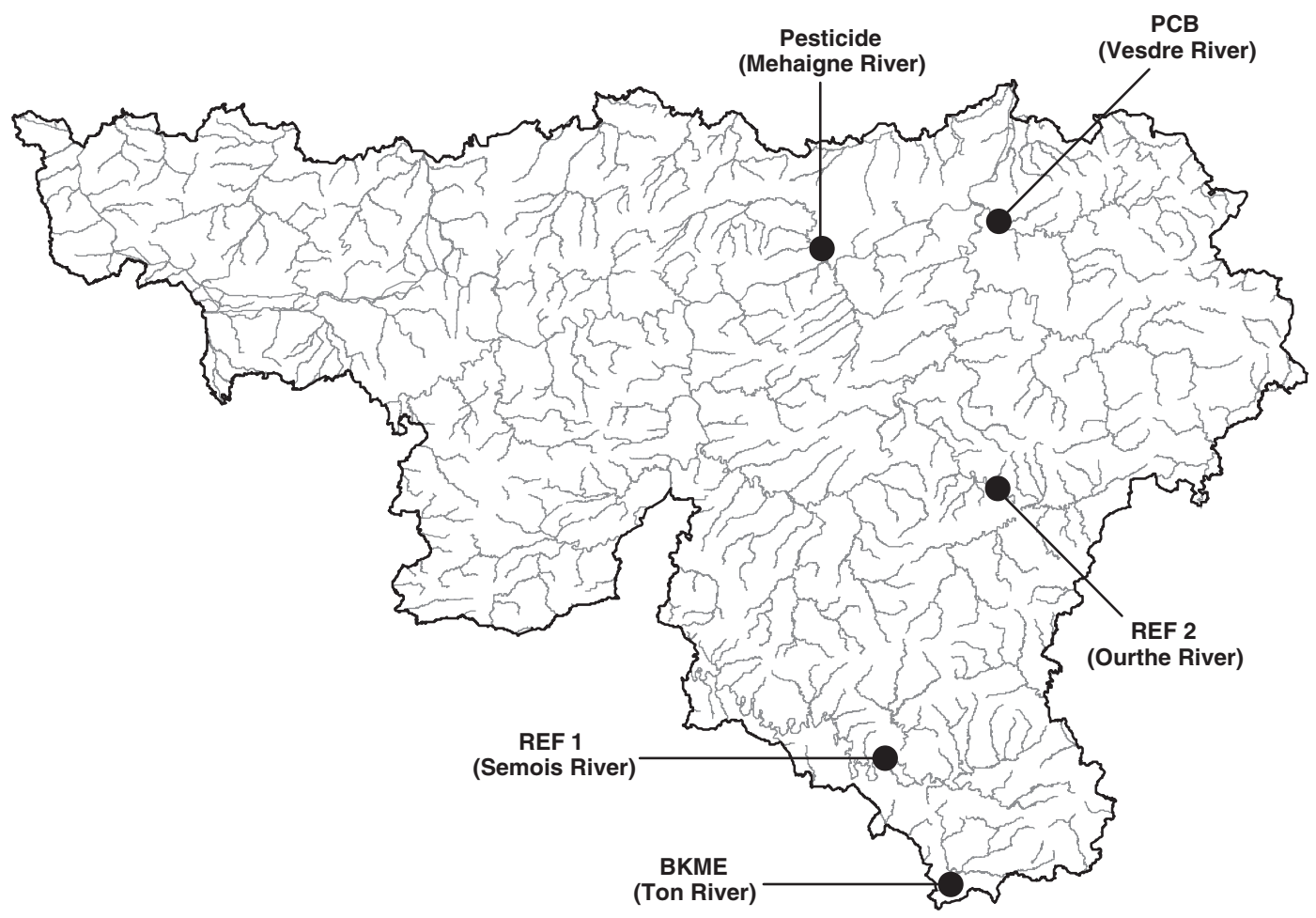

Fig. 1. Localization of the several sampling sites within the hydrographical network of southern Belgium. 
its position within an industrialized area and an important contamination by polychlorinated biphenyls (PCB), and the station Wanze, located in the Mehaigne River, because of its position within an agricultural area and a severe contamination by pesticides hexachlorocyclohexane and atrazine (MRW - DGRNE et coll., 2000; Cellule Etat de l'Environnement Wallon, 2003).

In order to reduce fish assemblage variations due to geographical factors and longitudinal gradient, all sampling sites were chosen within the same ecoregion (the Western Highlands, according to Illies (1978)), between the lower grayling zone and the lower barbel zone, according to Huet's (1949) zonation.

\subsection{Fish collection and tissue handling}

Fish were collected during the first two weeks of May 2003 by electrofishing. Sampling was carried out with two to three generator sets, depending on stream width, each generator set consisting of a $3 \mathrm{~kW}$ alternator delivering, after DC transformer, a direct current (300$400 \mathrm{~V}, 2-4 \mathrm{~A}$ ) and a fixed cathode. Fishing took place in two consecutive passages and catches from each passage were treated separately. All fish were measured and weighed individually. However, for small species with low individual weight, individuals were counted, pooled together and a group weight was taken. All the fish were then released in the field, except chubs dissected for tissue collection.

Chubs ranging from 30 to $40 \mathrm{~cm}$ were selected to ensure enough biological material. A quota of 5 females and 5 males were chosen for biochemical assays and histological routine except in the BKME contaminated site where no mature males were found. After capture, blood was collected from the caudal vein using a $1 \mathrm{ml}$ heparinized syringe. Blood samples were then stored in heparinized polyethylene tubes to inhibit clotting. Plasma was collected following centrifugation at $4500 \mathrm{rpm}$ at $10{ }^{\circ} \mathrm{C}$ for $20 \mathrm{~min}$ and stored at $-80{ }^{\circ} \mathrm{C}$ until assayed for sex steroids and alkali-labile phosphorus (ALP). Liver was rapidly excised and washed in an ice-cold buffer $(150 \mathrm{mM} \mathrm{KCl})$. Several aliquots were weighed and stored at $-80{ }^{\circ} \mathrm{C}$ for determination of ethoxyresorufin- $O$ deethylase (EROD) activity, gluthation- $S$-transferase (GST) activity and $70-\mathrm{kDa}$ stress protein (HSP70) concentration. Gonads were finally removed, weighed and fixed in Bouin's solution for histological examination.

\subsection{Polychlorinated biphenyls analysis}

PCB were extracted according to a slight modification of EPA method 608 as previously described by
Hugla et al. (1995). The acid and Florisil cleanup procedures and the chromatography separation of the PCB congeners in fish muscle, by means of highresolution capillary gas chromatography (HRGC), were also carried out according to Hugla et al. (1995) and Debier et al. (2003). Twenty-four individual PCB congeners (from di- to nonachlorinated) (IUPAC nos. $28,44,52,66,70,87,95,101,105,110,118,128,138$, $149,153,156,170,180,183,187,194,195,206,209)$ were identified and quantified, and PCB concentrations were expressed in $\mathrm{ng} \mathrm{g}^{-1}$ fresh weight.

\subsection{Biochemical measurements}

A liver aliquot was used to determine hepatic EROD activity. The liver samples were homogenized in icecold $\mathrm{Na}_{2} \mathrm{HPO}_{4} / \mathrm{KH}_{2} \mathrm{PO}_{4} 100 \mathrm{mM}$ buffer, $\mathrm{pH} 7.8$ with $20 \%$ glycerol (AFNOR NF T 90-385), PMSF $0.2 \mathrm{mM}$ (Flammarion et al., 1998b) with a Potter-Elvehjem homogenizer. Liver homogenates were centrifuged at $9000 \mathrm{~g}$ for $20 \mathrm{~min}$ at $4{ }^{\circ} \mathrm{C}$ and the resulting supernatants $\mathrm{S} 9$ stored in aliquots at $-80{ }^{\circ} \mathrm{C}$ until the measurement of EROD activity. EROD activities were measured according to a slight modification of the microplate procedure described by Flammarion et al. (1998a): the enzymatic activity was assayed in a final volume of $250 \mu \mathrm{l}$ containing $\mathrm{NaH}_{2} \mathrm{PO}_{4} / \mathrm{K}_{2} \mathrm{HPO}_{4}$ $100 \mathrm{mM}$ buffer, $\mathrm{pH} 7.8$, ethoxyresorufin $2 \mu \mathrm{M}$, NADPH $0.25 \mathrm{mM}$, and $25 \mu \mathrm{l}$ of supernatant S9. The reaction was followed for 2 min (AFNOR NF T 90385). Three triplicate determinations of each sample at a final concentration of $0.125,0.25$ and $0.5 \mathrm{mg}$ protein $\mathrm{ml}^{-1}$ were carried out, and resorufin standard curves were generated in order to convert fluorescent units to pmol of resorufin. Fluorescence was measured with a fluorometer Fluoroskan Ascent FL (excitation filter, $530 \mathrm{~nm}$; emission filter, $590 \mathrm{~nm}$ ), Thermo Electron Corporation (Vantaa, Finland). The protein content was determined by the method of Lowry et al. (1951) with a microplate procedure using TRU-Liquid Moni-Trol as standard.

Another liver section was used to evaluate hepatic GST activity. The liver sample was placed in 4 volumes of ice-cold buffer $(150 \mathrm{mM} \mathrm{KCl}, 5 \mathrm{mM}$ EDTA, $50 \mathrm{mM}$ Tris-HCl, pH 7.4) and homogenized on ice in a glass homogenizer (Kontes, USA) using a Teflon pestle at up to $2800 \mathrm{rpm}$ for two 15 -s periods with a 10 -s interval. GST activity was determined on cytosolic fractions $\left(100000 \times g, 60 \mathrm{~min}, 4{ }^{\circ} \mathrm{C}\right)$ using a protocol adapted from Habig et al. (1974). Enzymatic activity is expressed in nmol 1-chloro-2,4-dinitrobenzene (CDNB) conjugated $\min ^{-1} \mathrm{mg}$ protein ${ }^{-1}$. Protein 
content was assayed according to Lowry et al. (1951). All samples were assayed in duplicate.

A third liver sample was homogenized as described for the GST measurement in 3 volumes of ice-cold homogenization buffer (Trizma $50 \mathrm{mM}, \mathrm{NP}-40$ 1\%, pH 7.6, protease inhibitor cocktail $1 \mathrm{ml} / 20 \mathrm{~g}$ tissue, Sigma P8340). All soluble HSP70 were recovered in the supernatants by two consecutive centrifugations at $19800 \times g\left(4^{\circ} \mathrm{C}\right)$ for $30 \mathrm{~min}$. Total soluble protein concentration was determined using Bio-Rad Protein assay, based on the Bradford method using bovine serum albumin as standard. Samples were diluted in a TBS buffer (10 mM Tris-HCl, $150 \mathrm{mM} \mathrm{NaCl}, \mathrm{pH} 7.5$ ) plus SDS $0.1 \%$ and DTT $5 \mathrm{mM}$, and boiled for $5 \mathrm{~min}$. Three micrograms of proteins were directly loaded onto a nitrocellulose membrane $(0.45 \mu \mathrm{m})$ with a slot blotter (Bio-Dot SF microfiltration apparatus from BioRad). Human purified HSP70 (StressGen SPP-755) were used as standards at increasing quantities $(0.5-1-2.5-5 \mathrm{ng})$. Membranes were blocked for $1 \mathrm{~h}$ in 5\% dry milk TTBS (TBS plus $0.05 \%$ Tween 20, Merck), washed twice in TTBS and once in TBS for $5 \mathrm{~min}$, and then incubated for 90 min with the primary antibody (Affinity BioReagents MA3-006) at 1:5000 dilution in 2\% dry milk TTBS. Membranes were washed twice in TTBS and once in TBS for $5 \mathrm{~min}$ and incubated for $90 \mathrm{~min}$ with the secondary antibody (alkaline phosphatase-conjugated goat anti-mouse antibody, Sigma A3562) at 1:2000 dilution. Blots were then visualized in a mix of $37.5 \mu \mathrm{l}$ BCIP (Roche) and $50 \mu \mathrm{l}$ NBT (Roche) in $10 \mathrm{ml}$ of buffer solution (Tris $0.1 \mathrm{M}, \mathrm{MgCl} 20.05 \mathrm{M}, \mathrm{pH}$ 9.5). Membranes were dried and scanned (Amersham ImageScanner) and the hepatic HSP70 levels were determined by densitometry using ImageMaster TotalLab software (Amersham). The data are reported as $\mu \mathrm{g}$ equivalents HSP70 per mg of total soluble proteins. The specificity of the primary antibody was tested using SDS-PAGE and western blotting. In the chub hepatic soluble protein fraction, it recognizes one HSP70 isoform at about $70 \mathrm{kDa}$ and does not cross react with other protein (results not shown).

\subsection{Reproductive parameters}

Liver somatic index (LSI) was calculated as (liver weight $\times 100$ )/body weight. Gonadosomatic index GSI was calculated as (gonad weight $\times 100$ )/body weight.

Plasma concentrations of testosterone (T), estradiol$17 \beta$ (E2), and 11-ketotestosterone (11-KT) were determined by radio-immunoassay (RIA) according to Fostier and Jalabert (1986). Samples of $50 \mu 1$ of plasma for each steroid were extracted twice with cyclohexane/ ethylacetate $(\mathrm{v} / \mathrm{v})$. All samples were assayed in duplicate. Anti-T and anti-E2 were purchased at the Laboratoire d'Hormonologie de Marloie, anti-11-KT was a gift from Dr. A. Fostier (INRA, Rennes, France). All the radioactive hormones were purchased from Amersham Pharmacia. Coefficients of variation and detection limits were as reported by Mandiki et al. (2005).

Central part of each ovary were embedded in paraffin, cut at $6 \mu \mathrm{m}$ sections and stained with Masson's trichrome using hemalum, phloxine and light green (Langeron, 1942). For each section analyzed, 200 oocytes were scored and the proportion of oocytes at each stage of development was calculated according to the classification of Kestemont (1987) modified by Rinchard and Kestemont (1996) (Table 1). Only oocytes cut through the nucleus were considered in the present study. Atretic oocytes were also considered.

Among the various methods developed to quantify vittelogenin, plasma alkali-labile phosphorus (ALP) measurements displayed a similar sensitivity as that of antibody-based assays with the advantage of being rapid, easy and inexpensive (Verslycke et al., 2002). ALP, as ortho-phosphate released from vitellogenin, was extracted from $30 \mu \mathrm{l}$ of plasma according to Wallace and Jared (1968). Ortho-phosphates were determined through measurement of

Table 1

Microscopic characteristics for the determination of the different oocyte stages (modified from Kestemont, 1987; Rinchard and Kestemont, 1996)

Oocyte stage development Description

(1) Protoplasmic oocytes

Small oocytes with vacuole free

(2) Onset of endogenous vitellogenesis

Appearance of yolk vesicles, occupy 2 or 3 rings in the cytoplasm periphery

(3) Completion of endogenous vitellogenesis

(4) Exogenous vitellogenesis

(5) Final maturation Oocytes are full of yolk vesicles. Follicular and cellular layers are differentiated

Oocytes accumulate yolk globules and yolk vesicles are at the periphery of the cytoplasm Appearance of the micropyle and migration of the germinal vesicle to the micropyle

Ovule

Post-ovulatory atretic follicles

Detachment of oocytes from the follicular layer, oocytes expulsion Hypertrophia of the granulosa cells, empty follicle after oocyte expulsion

Preovulatory atretic follicles
Hypertrophia of the granulosa cells, layers disorganization, cytoplasm autolysis 
acidified phosphomolybdate complexes by spectrophotometry (phosphomolybdenum method, Sigma 670-A, Steinheim, Germany).

\subsection{Population and community assessment}

All chubs were measured individually, except the youngest fish $(50-90 \mathrm{~mm})$ that were counted and considered altogether when weighing in the field. As the sampling took place in the early spawning period, chubs with a length $<130 \mathrm{~mm}$ were considered as juveniles according to Kosmala (1998).

Analysis of fish assemblages was performed according to a fish-based index (IBI) modified from Kestemont et al. (2000) to cope with the European Water Framework Directive requirements (Council of European Communities, 2000). This index is derived from the IBI proposed by Karr et al. (1986) and adapted to European ichtyofauna (Hughes and Oberdorff, 1998). It provides a general assessment of environmental quality by measuring several aspects of fish species composition, richness and abundance. The six metrics used for calculating the IBI were scored against values expected under reference conditions. Each metric received a score between 1 and 5, with 1 being the best and 5 being the worst possible of each individual metric (Table 2). The IBI score, ranging from 6 (excellent) to 30 (very poor), was found by summing all the metric scores.

\subsection{Statistical analysis}

Data sets were transformed $(\log 10)$ and homogeneity of variances was verifed using Brown-Forsythe's test. Sex and sites effects were analyzed using analysis of variance (ANOVA) tests. When the ANOVA rejected a multisample null hypothesis of equal means $(p<0.05)$, the Tuckey HSD for unequal $N$ post hoc test was used to determine significant differences in response variables between sites. Non-parametric Kruskal-Wallis and Mann-Whitney $U$ tests were performed in cases where data sets did not meet assumptions of analysis of variance (hepatic EROD activity data). Proportion Chi-square test was used to compare the distribution of oocyte stages and to complete the chub populations analysis. Differences were considered significant at the level $p<0.05$.

\section{Results}

\section{1. $P C B$ analysis}

PCB concentrations in muscles of chubs caught at the different sampling stations are shown in Table 3. PCB values reached $61 \pm 68 \mathrm{ng} \mathrm{g}^{-1}$ fresh weight in male chubs and $79 \pm 141 \mathrm{ng} \mathrm{g}^{-1}$ fresh weight in females. PCB accumulation did not show a sex-dependent difference $(p>0.05)$. Chubs from the PCB and pesticide contaminated site show significantly higher muscular PCB concentrations than those from reference site 1 and from

Table 2

Selected metrics and scoring criteria of IBI to evaluate the ecological quality of wadable streams and rivers (modified from Kestemont et al., 2000)

\begin{tabular}{|c|c|c|c|c|c|}
\hline \multirow{2}{*}{$\begin{array}{l}\text { Categories } \\
\text { metrics }\end{array}$} & \multicolumn{5}{|l|}{ Scoring Criteria } \\
\hline & 1 & 2 & 3 & 4 & 5 \\
\hline \multicolumn{6}{|c|}{ Indicators of species richness } \\
\hline $\begin{array}{l}\text { 1. Number of native } \\
\text { species }\end{array}$ & $\begin{array}{l}\text { Varies with } \\
\text { stream size }\end{array}$ & & & & \\
\hline $\begin{array}{l}\text { 2. Number of benthic } \\
\text { species }\end{array}$ & $\begin{array}{l}\text { Varies with } \\
\text { stream size }\end{array}$ & & & & \\
\hline \multicolumn{6}{|c|}{ Indicators of water quality } \\
\hline $\begin{array}{l}\text { 3. \% intolerant } \\
\text { individuals }\end{array}$ & $\begin{array}{l}\text { Varies with } \\
\text { stream size }\end{array}$ & & & & \\
\hline $\begin{array}{l}\text { 4. Bullhead/ } \\
\text { bullhead+loach }\end{array}$ & $>0.8$ & $0.6-0.8$ & $0.4-0.6$ & $0.2-0.4$ & $<0.2$ \\
\hline \multicolumn{6}{|c|}{ Indicators of physical habitat } \\
\hline $\begin{array}{l}\text { 5. \% individuals as } \\
\text { specialized }\end{array}$ & $>67$ & - & $33-67$ & - & $<33$ \\
\hline $\begin{array}{l}\text { 6. Presence of fry, } \\
\text { juveniles and adults } \\
\text { in the dominant } \\
\text { species among the } \\
\text { intolerant ones }\end{array}$ & $\begin{array}{l}\text { (a) Fry-juveniles-adults } \\
\text { (>50 individuals) }\end{array}$ & $\begin{array}{l}\text { (b) Fry-juveniles-adults } \\
\text { ( }<50 \text { individuals) or } \\
\text { (c) absence of one stage } \\
\text { ( }>50 \text { individuals) }\end{array}$ & $\begin{array}{l}\text { (d) Absence of } \\
\text { one stage } \\
\text { ( }<50 \text { individuals) }\end{array}$ & $\begin{array}{l}\text { (e,f) Absence of } \\
\text { two stages }\end{array}$ & $\begin{array}{l}\text { (g) No intolerant } \\
\text { species }\end{array}$ \\
\hline
\end{tabular}


Table 3

Muscular concentration of 24 PCB congeners, hepatic GST activity and HSP70 concentration in chubs caught at the different sampling stations

\begin{tabular}{|c|c|c|c|c|c|}
\hline & REF 1 & REF 2 & BKME & PCB & Pesticides \\
\hline $\begin{array}{l}24 \text { PCB congeners in muscles } \\
\text { (mean site value; } \mathrm{ng} \mathrm{g}^{-1} \text { fresh weight) }\end{array}$ & $8 \pm 6^{\mathrm{a}}$ & - & $11 \pm 6^{\mathrm{a}}$ & $210 \pm 143^{b}$ & $41 \pm 23^{\mathrm{c}}$ \\
\hline $\begin{array}{l}\text { Hepatic GST activity } \\
\quad\left(\text { nmol } \min ^{-1} \mathrm{mg} \text { protein }\right.\end{array}$ & $0.236 \pm 0.048$ & $0.163 \pm 0.051$ & $0.237 \pm 0.056$ & $0.246 \pm 0.095$ & $0.235 \pm 0.064$ \\
\hline $\begin{array}{l}\text { Hepatic HSP70 concentration } \\
\quad\left(\mu \mathrm{g} \text { HSP70 } \mathrm{mg}^{-} \text {protein }^{-1}\right)\end{array}$ & $4.37 \pm 0.93$ & $4.99 \pm 2.47$ & $4.21 \pm 1.20$ & $4.25 \pm 1.41$ & $4.23 \pm 1.01$ \\
\hline
\end{tabular}

Values not sharing a common superscript within a line are statistically different from each other $(p<0.05)$.

the BKME contaminated site $(p>0.001)$. However, significantly lower PCB values were found in chubs from the pesticide contaminated site compared to fish caught at the PCB contaminated site $(p>0.01)$. No data were available for chubs from reference site 2 .

\subsection{Biochemical measurements}

The hepatic EROD activity of chubs captured at the different sampling stations is shown in Fig. 2. The mean EROD activity in males was significantly more elevated than in females $(p<0.001)$. In female chubs, the EROD activity ranged from $0.17 \pm$ $0.18 \mathrm{pmol} \mathrm{min}^{-1} \mathrm{mg}$ protein ${ }^{-1}$ (reference site 2) to $6.95 \pm 3.28 \mathrm{pmol} \mathrm{min}^{-1} \mathrm{mg}$ protein ${ }^{-1}$ (BKME contaminated site). Females caught at the BKME and PCB contaminated sites had a significantly higher EROD activity than those from both reference sites (BKME: $p<0.001$; PCB: $p<0.05$ ) while a significantly higher EROD activity was found in female chubs from the pesticide contaminated site compared to those sampled at reference site $1(p<0.05)$. In males, the EROD activity ranged from $6.43 \pm 0.59 \mathrm{pmol} \mathrm{min}^{-1} \mathrm{mg}$ protein ${ }^{-1}$ (reference site 1) to $17.70 \pm 7.01 \mathrm{pmol} \mathrm{m^{-1 }} \mathrm{mg}$ protein $^{-1}$ (pesticide contaminated site). The EROD activity of male chubs from the pesticide contaminated site was significantly higher than in male chubs sampled at reference site $1(p<0.01)$ and $2(p<0.05)$. No data were available for males at the BKME contaminated site.

GST values did not appear to be sex-dependent ( $p>$ $0.05)$. No significant difference of GST activity was observed between chubs from the different stations $(p>0.05)$ (Table 3). As for GST activity, the level of hepatic HSP70 was not sex-dependent $(p>0.05)$. No significant difference was found between levels of HSP70 in chubs caught at the different sampling locations $(p>0.05)$ (Table 3$)$.

\subsection{Reproductive parameters}

Liver somatic index, gonadosomatic index and plasma sex steroids levels of chubs captured at the various sampling stations are shown in Table 4. Liver somatic index (LSI) did not differ significantly $(p>0.05)$ between sampling stations, whether the values were based on both sexes together or on males or females separately. However, LSI was significantly higher in females $(1.42 \pm 0.43)$ than in males $(1.09 \pm 0.25)$ $(p<0.01)$. Gonadosomatic index averaged 10.2 \pm 5.16 in females and $5.0 \pm 2.47$ in males, without any differences between stations $(p>0.05)$.

Plasma 11-KT concentrations were significantly lower $(p<0.05)$ in female chubs $\left(1.4 \pm 1.2 \mathrm{ng}^{-1}\right)$ than in males $\left(2.4 \pm 1.9 \mathrm{ng} \mathrm{l}^{-1}\right)$. Female chubs from reference site $1 \mathrm{had}$ a significantly lower level of $11-\mathrm{KT}$ than those sampled in
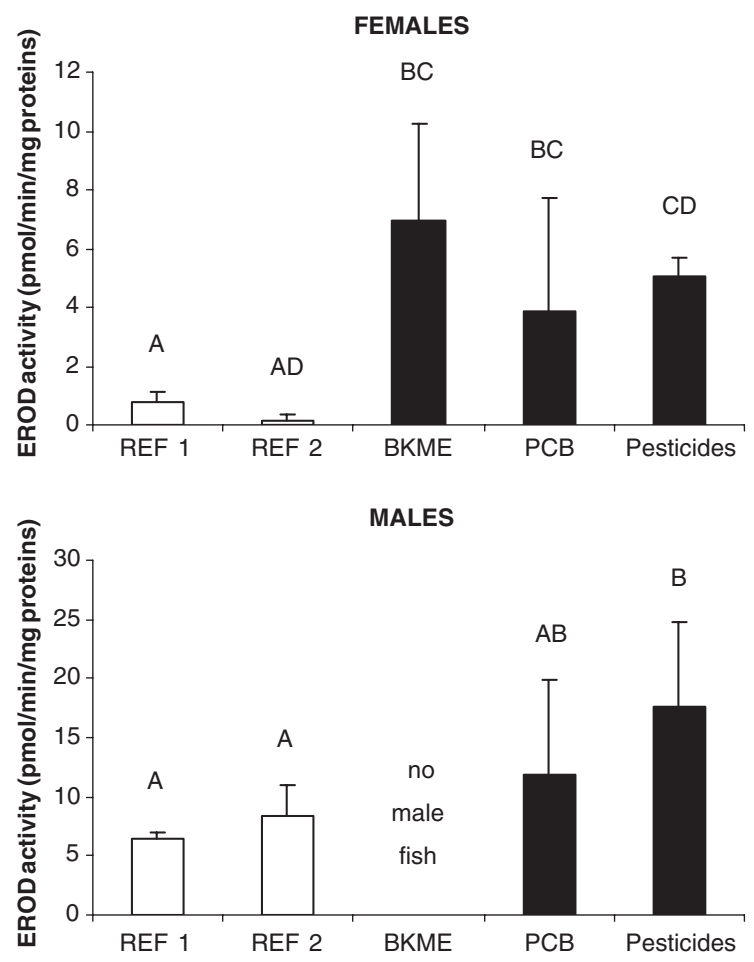

Fig. 2. Hepatic EROD activity of chubs caught at the various sampling sites. The reference sites are shown in white. Data are means +SD. Values not sharing a common letter whithin a graphic are statistically different from each other (Mann-Whitney $U$ test, $p<0.05$ ). 
Table 4

Liver somatic index, gonadosomatic index and plasma sex steroids levels of chubs caught at the different sampling sites

\begin{tabular}{|c|c|c|c|c|c|}
\hline & REF 1 & REF 2 & BKME & PCB & Pesticides \\
\hline \multicolumn{6}{|l|}{ Females } \\
\hline LSI & $1.52 \pm 0.59$ & $1.67 \pm 0.50$ & $1.43 \pm 0.36$ & $1.02 \pm 0.31$ & $1.35 \pm 0.50$ \\
\hline GSI & $10.7 \pm 5.8$ & $5.9 \pm 1.4$ & $13.2 \pm 3.6$ & $14.0 \pm 6.4$ & $9.0 \pm 5.9$ \\
\hline Plasma 11-KT (ng $1^{-1}$ ) & $0.51 \pm 0.52^{\mathrm{a}, *}$ & $2.39 \pm 1.34^{\mathrm{bc}}$ & $1.50 \pm 1.09^{\mathrm{ac}}$ & $2.39 \pm 1.28^{\mathrm{bc}, *}$ & $1.71 \pm 1.08^{\mathrm{ac}}$ \\
\hline Plasma T (ng $\left.1^{-1}\right)$ & $8.13 \pm 6.24$ & $9.98 \pm 10.91$ & $9.85 \pm 11.27$ & $2.87 \pm 3.69$ & $4.10 \pm 0.58$ \\
\hline Plasma E2 (ng 1 $\left.{ }^{-1}\right)$ & $7.52 \pm 5.81$ & $11.43 \pm 10.13$ & $8.92 \pm 4.43$ & $6.22 \pm 1.82$ & $4.19 \pm 3.41$ \\
\hline \multicolumn{6}{|l|}{ Males } \\
\hline LSI & $1.23 \pm 0.19$ & $0.82 \pm 0.31$ & - & $0.83 \pm 0.29$ & $1.15 \pm 0.19$ \\
\hline GSI & $4.9 \pm 0.7$ & $4.3 \pm 0.5$ & - & $5.2 \pm 2.5$ & $6.2 \pm 3.4$ \\
\hline Plasma 11-KT (ng $1^{-1}$ ) & $4.58 \pm 2.71^{\mathrm{a}, *}$ & $1.86 \pm 0.41^{\mathrm{ab}}$ & - & $2.05 \pm 1.25^{\mathrm{ab}}$ & $1.43 \pm 0.79^{\mathrm{b}, *}$ \\
\hline Plasma $T\left(n g 1^{-1}\right)$ & $10.85 \pm 6.94$ & $3.94 \pm 2.49$ & - & $4.17 \pm 2.49$ & $5.15 \pm 3.88$ \\
\hline Plasma E2 (ng 1 $\left.{ }^{-1}\right)$ & $4.81 \pm 2.36$ & $1.77 \pm 0.57$ & - & $4.86 \pm 2.37$ & $5.81 \pm 3.82$ \\
\hline
\end{tabular}

Values not sharing a common superscript within a line are statistically different from each other $(p<0.05)$. Data sharing an asterisk are highly different from each other $(p<0.01)$.

the PCB contaminated site $(p<0.01)$ and in reference site $2(p<0.05)$. A significantly higher level of $11-\mathrm{KT}$ was also assayed in males sampled in reference site 1 compared to the values of males sampled in the pesticide contaminated site $(p<0.01)$. Plasma $\mathrm{T}$ levels were similar in females $\left(8.1 \pm 8.6 \mathrm{ng} \mathrm{l}^{-1}\right)$ and males $(5.7 \pm$ $\left.5.1 \mathrm{ng}^{-1}\right)(p>0.05)$ while plasma E2 concentrations were significantly higher in females $\left(8.2 \pm 5.5 \mathrm{ng} \mathrm{l}^{-1}\right)$ than in males $\left(5.2 \pm 3.9 \mathrm{ng} \mathrm{l}^{-1}\right)(p<0.05)$. Levels of E2 and T did not differ significantly between fish sampled at the different sites $(p>0.05)$, neither in females, norin males.

Plasma levels of ALP are shown in Fig. 3. As for E2 and $\mathrm{T}$, levels of ALP were not significantly different between stations, neither in females, nor in males. However, levels in females were always significantly higher than in males $(p<0.05)$, except for chubs from the pesticide contaminated site $(p>0.05)$.

Distributions of oocyte stages in ovaries of chubs caught at different sampling stations are shown in Fig. 4. Stage 1 (protoplasmic oocytes) was the most abundant stage in chub ovaries in the early spawning season, ranging from $59.2 \%$ in fish from reference site 1 to $66.8 \%$ in fish caught in the BKME contaminated site. The proportions of stage 2 oocytes (onset of endogenous vitellogenesis) ranged from $5.0 \%$ (pesticide contaminated site) to $16.3 \%$ (reference site 1) while stage 3 oocytes (complete endogenous vitellogenesis) were less numerous (from $1.1 \%$ in fish from the PCB contaminated site to $8.4 \%$ in fish from the pesticide contaminated site). The proportions of stage 4 oocytes (exogenous vitellogenesis) ranged from $7.3 \%$ (PCB contaminated site) to $13.8 \%$ (reference site 1). Stage 5 oocytes (final maturation) were very rare, even missing in ovaries of chubs caught at reference site 2 , and never exceeded $0.6 \%$ (pesticide contaminated site). Ovules were observed in chubs from the PCB contaminated site $(1.1 \%)$ only. Post-ovulatory follicles were observed in fish from all stations, from $0.5 \%$ in fish sampled in the BKME contaminated site to $15.2 \%$ in fish sampled in the PCB contaminated site. The oocyte distribution of chubs from the pesticide contaminated site was the only one to differ significantly $(p<0.05)$ from the distributions observed at the two reference sites.

The proportion of preovulatory atretic follicles was significantly affected by the site of sampling $(p<0.05)$, ranging from $1.0 \%$ in fish from reference site 1 to $9.7 \%$ in fish sampled at the pesticide contaminated site (Fig. 5). Chubs from the pesticide contaminated site had a significantly higher proportion of atretic follicles than fish from both reference sites $(p<0.05)$.

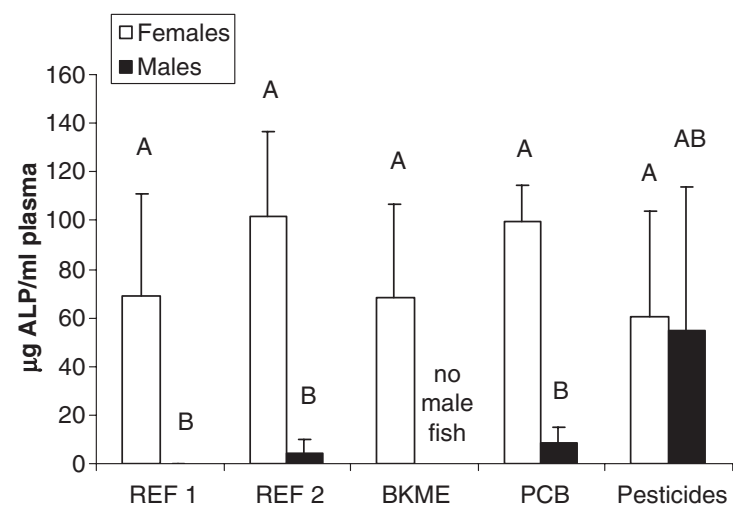

Fig. 3. Plasma alkali-labile phosphorus in chubs caught at the various sampling sites. Females are shown in white and males in black. Data are means $+\mathrm{SD}$. Values not sharing a common letter are statistically different from each other (Tuckey HSD for unequal $N$ post hoc test, $p<0.05)$. 


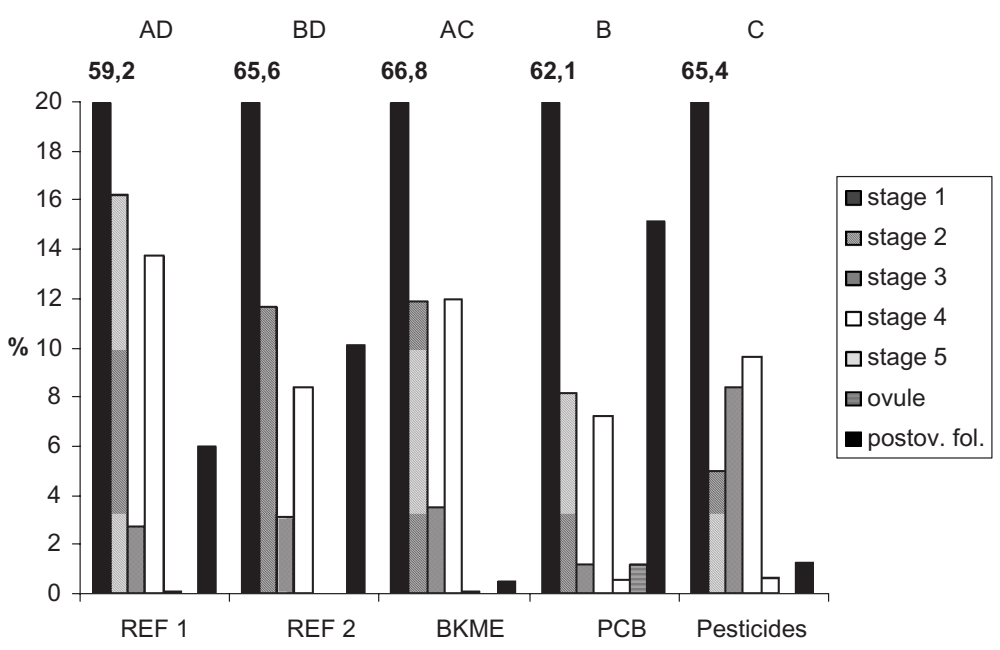

Fig. 4. Distributions of oocyte stages in ovaries of chubs caught at the various sampling sites. Data are relative frequencies (\%) of each stage in ovaries of the mean individual for every site. The bars for stage 1 oocytes are truncated and the real observed frequency is given above each. Sites not sharing a common letter present a statistically different stages distribution from each other (Proportions Chi-square test, $p<0.05$ ).

\subsection{Population analysis}

Both reference sites had a well-balanced chub population with a predominant cohort of young fish, ranging between 50 and $130 \mathrm{~mm}$, and older individuals belonging to different larger size classes, while the three other sites revealed a disrupted size distribution. In BKME and pesticide contaminated sites, the proportion of young fish was clearly under-represented, while in the PCB contaminated site, the total number of chubs was very low, and quite exclusively represented by juveniles. The juveniles $(<130 \mathrm{~mm}) /$ adults $(>130 \mathrm{~mm})$ ratios for chubs caught at the BKME contaminated site and at the pesticide

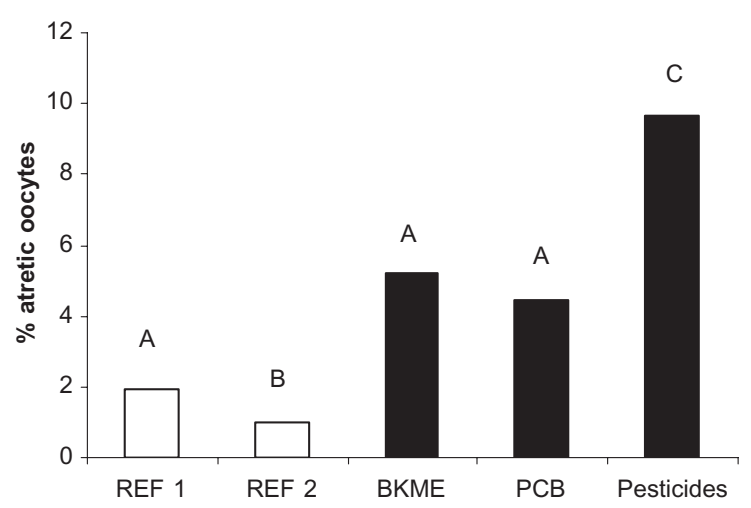

Fig. 5. Proportions of preovulatory atretic follicles in ovaries of chubs caught at the various sampling sites. The reference sites are shown in white. Data are relative frequencies of preovulatory atretic follicles in ovaries of the "mean individual" for every site. Values not sharing a common letter are statistically different from each other (Proportions Chi-square test, $p<0.05$ ). contaminated site were significantly different $(p<0.05)$ from the ones observed at the two reference sites (Fig. 6).

\subsection{Fish community assessment}

Information about the fish captured at the 5 stations studied is summarized in Table 5. A total of 7844 individuals were sampled representing 19 species. The total number of individuals and the total number of species per station varied between 501-2492 and 7-17, respectively.

Data for the various metrics and the corresponding values as well as IBI scores are shown in Table 6. There

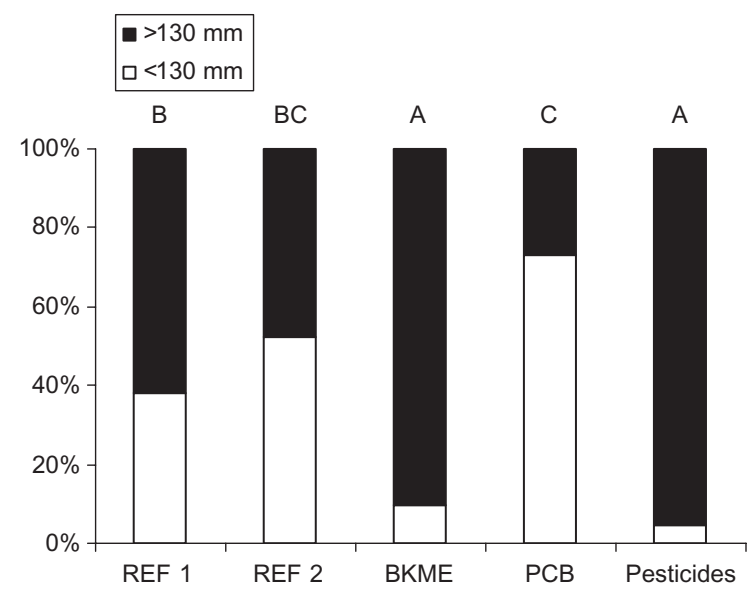

Fig. 6. Distribution of juvenile $(<130 \mathrm{~mm})$ and adult $(>130 \mathrm{~mm})$ chubs in the various sampling sites. Data are relative frequencies. Values not sharing a common letter are statistically different from each other (Proportions Chi-square test, $p<0.05$ ). 
Table 5

Taxonomic classification and abundance (total captured number) of fish caught at the different sampling stations

\begin{tabular}{|c|c|c|c|c|c|c|}
\hline \multirow[t]{2}{*}{ Family } & \multirow[t]{2}{*}{ Species } & \multicolumn{5}{|c|}{ Sampling stations } \\
\hline & & REF 1 & REF 2 & BKME & PCB & Pesticides \\
\hline Anguillidae & Anguilla anguilla & 2 & 1 & & & 3 \\
\hline Balitoridae & Barbatula barbatula & 86 & 261 & 74 & 101 & 3 \\
\hline Cottidae & Cottus gobio & 347 & 448 & & & 26 \\
\hline \multirow[t]{11}{*}{ Cyprinidae } & Abramis brama & 1 & & & & \\
\hline & Alburnoides bipunctatus & 3 & 19 & 3 & & 1 \\
\hline & Alburnus alburnus & 22 & & & & 48 \\
\hline & Barbus barbus & 53 & 29 & 7 & & 1 \\
\hline & Blicca bjoerkna & & & & & 3 \\
\hline & Chondrostoma nasus & 13 & & 1 & & 12 \\
\hline & Gobio gobio & 237 & 37 & 307 & 66 & 212 \\
\hline & Leuciscus cephalus & 79 & 39 & 62 & 15 & 127 \\
\hline & Leuciscus leuciscus & 93 & 5 & 20 & 3 & 8 \\
\hline & Phoxinus phoxinus & 1451 & 530 & 1068 & 226 & \\
\hline & Rutilus rutilus & 64 & & 11 & & 1419 \\
\hline Gasterosteidae & Gasterosteus aculeatus & & & & 50 & \\
\hline \multirow[t]{2}{*}{ Percidae } & Gymnocephalus cernua & 15 & 1 & & & \\
\hline & Perca fluviatilis & 4 & & 4 & & 3 \\
\hline Salmonidae & Salmo trutta & 18 & 46 & 1 & & 9 \\
\hline \multirow[t]{3}{*}{ Thymallidae } & Thymallus thymallus & 4 & & 2 & 40 & \\
\hline & Total number of fish & 2492 & 1416 & 1560 & 501 & 1875 \\
\hline & Total number of species & 17 & 11 & 12 & 7 & 14 \\
\hline
\end{tabular}

were obvious differences in species composition and abundance resulting in different metric scores between sampling stations. The overall IBI values ranged from 9 to 23 , corresponding to fish communities rated as excellent to poor. Fish community at reference site 1 fell in the excellent category with a total score of 9 . The IBI metrics for this location obtained the highest possible score, except for the percentage of intolerant individuals. Fish community at reference site 2 was classified in the good category (score of 12). The other fish communities were considered as either fair (pesticide contaminated site) or poor (BKME contaminated site and PCB contaminated site). The major factors contributing in lower IBI values were fewer intolerant individuals and poorer bullhead (Cottus gobio)/bullhead + loach (Barbatula barbatula) ratios.

\section{Discussion}

The biological status of fish living in diversely impacted sites was assessed by a multiparametric approach using different indicators at various levels of organization. Two sampling sites were selected as references, while three other stations were considered

Table 6

Metrics and values used to calculate the IBI score for the various sampling sites

\begin{tabular}{|c|c|c|c|c|c|c|c|c|c|c|}
\hline & \multicolumn{2}{|l|}{ REF 1} & \multicolumn{2}{|l|}{ REF 2} & \multicolumn{2}{|c|}{ BKME } & \multicolumn{2}{|l|}{ PCB } & \multicolumn{2}{|c|}{ Pesticides } \\
\hline & Value & $\begin{array}{l}\text { Metric } \\
\text { score }\end{array}$ & Value & $\begin{array}{l}\text { Metric } \\
\text { score }\end{array}$ & Value & $\begin{array}{l}\text { Metric } \\
\text { score }\end{array}$ & Value & $\begin{array}{l}\text { Metric } \\
\text { score }\end{array}$ & Value & $\begin{array}{l}\text { Metric } \\
\text { score }\end{array}$ \\
\hline Number of native species & 16 & 1 & 10 & 3 & 12 & 2 & 7 & 4 & 14 & 2 \\
\hline Number of benthic species & 7 & 1 & 6 & 2 & 3 & 3 & 2 & 4 & 5 & 2 \\
\hline$\%$ of intolerant individuals & 17 & 4 & 37 & 2 & 0.7 & 5 & 8 & 5 & 2 & 5 \\
\hline Bullhead/bullhead+loach ratio & 0.8 & 1 & 0.6 & 2 & 0 & 5 & 0 & 5 & 0.9 & 1 \\
\hline$\%$ of individuals as specialized spawners & 86 & 1 & 97 & 1 & 79 & 1 & 77 & 1 & 10 & 5 \\
\hline $\begin{array}{l}\text { Presence of fry, juveniles and adults in the } \\
\text { dominant species among the intolerant ones }\end{array}$ & $\mathrm{a}$ & 1 & $\mathrm{~b}$ & 2 & $\mathrm{~d}$ & 3 & $\mathrm{f}$ & 4 & $\mathrm{~d}$ & 3 \\
\hline IBI score & 9 & & 19 & & 12 & & 23 & & 18 & \\
\hline
\end{tabular}


as polluted either by paper mill effluents (BKME), polychlorinated biphenyls (PCB), or pesticides. The indicators used in this study were categorized as biochemical responses, reproductive parameters, population analysis and fish community assessment.

\subsection{Biochemical measurements}

As previously reported by Masfaraud et al. (1990) and Vindimian et al. (1991), a sex-related difference was found in the hepatic EROD activity of chubs caught at the different stations. This difference was probably due to the influence of sex steroids, and particularly estradiol-17 $\beta$, on hepatic mono-oxygenase activity (Vodicnik and Lech, 1983; O'Hare et al., 1995). In female chub, hepatic EROD activity was significantly higher in individuals sampled in the BKME and PCB contaminated sites than in both reference sites. This is in agreement with the EROD inducing activity of paper mill effluents (Soimasuo et al., 1995; Coakley et al., 2001) and PCB (Addison et al., 1982; Hugla and Thomé, 1999). Moreover, EROD activity in females from the pesticide contaminated site was higher than in chubs from reference 1, revealing the exposure of fish to EROD inducer(s). PCB are the likely EROD inducers in chubs from the PCB contaminated site since high muscular concentrations were found in chubs from this station. However, other compounds may have induced EROD in chubs from the BKME and pesticide contaminated sites, since lower PCB values were observed in muscles of fish caught at both stations. It has been shown that atrazine and hexachlorocyclohexane, both recorded in the pesticide contaminated site (MRW-DGRNE et coll., 2000; Cellule Etat de l'Environnement Wallon, 2003), could cause an increased hepatic EROD activity in treated organisms (Hanioka et al., 1998; Parmar et al., 2003). However, the EROD inducing activity of such compounds has not been clearly established in fish (Egaas et al., 1993; Arukwe et al., 2000), suggesting that additional EROD inducers like dioxins (Hahn, 2002) or polycyclic aromatic hydrocarbons (Bosveld et al., 2002) might be present in those stations. When comparing males, only chubs from the pesticide contaminated site showed a significantly higher EROD activity than those from reference sites, corroborating the presence of EROD inducer(s) in this station. Surprisingly, hepatic EROD activity in male fish from the PCB contaminated site did not differ significantly from the activity observed in chubs from reference sites. This could be explained by the presence of EROD inhibiting substances such as metallic compounds (Viarengo et al., 1997; Bozcaar- mutlu and Arinç, 2004) additionally contaminating the PCB station which recently sustained an acute pollution by aluminium, as much as it recovers from heavy copper pollution, a legacy of the industrial past.

As observed in various studies (Soimasuo et al., 1995; Behrens and Segner, 2001), hepatic GST activity was not significantly different in chubs from contaminated sites than in fish from reference stations. This biomarker has proved less dependable as indicator of environmental contamination (van der Oost et al., 2003). In the same way, hepatic levels of stress protein HSP70 did not differentiate between contaminated and reference sites, although several authors have considered heat shock proteins a useful biomarker in case of contaminations with either BKME (Vijayan et al., 1998) or pesticides (Bagchi et al., 1996). However, according to Pyza et al. (1997), HSP70 content in an animal body is not clearly correlated with exposure to harmful chemicals, and therefore cannot be considered as a universal biomarker for ecotoxicological studies.

\subsection{Reproductive parameters}

The sex-related difference in liver somatic index can be explained by the maturation stage of chubs, considering that during vitellogenesis the liver of females is stimulated to produce vitellogenin. It has been shown that the increase of liver weight is caused by the proliferation of endoplasmic reticulum and Golgi apparatus in hepatocytes (Rinchard et al., 1998). As sampling took place during the early spawning season of chub, female fish were still in vitellogenesis and therefore displayed higher LSI than males. Moreover, it has been reported by several authors (Poncin, 1988; Kestemont and Philippart, 1991) that under appropriate environmental conditions, chub can reproduce several times (with a continuous process of vitellogenesis) during a single reproductive season. Plasma 11-KT concentrations assayed in chubs caught at the different sampling sites were, as expected, higher in males than in females, regardless of the sampling stations. In males, plasma 11-KT concentrations in fish from reference site 1 were higher than in chubs from the pesticide contaminated site. A suppression of plasma 11-KT has also been shown in male goldfish (Carassius auratus) exposed to atrazine (Spanò et al., 2004), this herbicide being present in the pesticide contaminated station. Moreover, it has been reported that hexachlorocyclohexane could cause a reduction in plasma sex steroids levels in exposed male and female catfish (Heteropneustes fossilis) (Singh and Canario, 2004). No significant differences in plasma $\mathrm{T}$ concentrations were found 
between male and female chubs, due to a high interindividual variability while plasma E2 concentrations were significantly higher in females than in males. However, no significant differences between sites were noted on the basis of those sex steroids, in contrast to the findings of several authors who actually observed altered concentrations in fish exposed to different xenobiotics such as BKME (McMaster et al., 1995; Janz et al., 1997) or industrial effluents (Sepúlveda et al., 2002). This could be due to the important variability of plasma sex steroid levels during the spawning season (Hecker, 2001).

The induction of vitellogenesis in male fish has been widely used as a biomarker for endocrine disruption (Kime et al., 1999). Vitellogenin levels did not differ among chubs from the different sampling sites because of the high variability in endocrine status during the spawning season. However, levels in females were always significantly higher than in males, except at the pesticide contaminated site where several male chubs displayed similar ALP values than females. This suggests that those fish were exposed to estrogenic compounds. Such results are in apparent contradiction with Spanò et al. (2004) who failed to observe any vitellogenin induction in male goldfish exposed to atrazine during three weeks. However, although atrazine has been detected in the pesticide contaminated site, it has been shown by several authors that other chemicals present in the aquatic environment such as natural and synthetic estrogens, or non-ionic surfactants and other pesticides (Sumpter, 1998; Solé et al., 2001) display estrogenic activity. Hexachlorocyclohexane, which has been detected in the pesticide contaminated site, has been reported to have such estrogenic activity in fish (Wester and Canton, 1986).

Histological observations of chubs ovaries corroborate the fact that chub is a multiple spawner (Nunn et al., 2002; Fredrich et al., 2003) since stage 4 oocytes (exogenous vitellogenesis) were still present in fish that had already laid a first batch of eggs (presence of postovulatory atretic follicles in ovaries). However, the differences found in the distribution of oocyte stages in ovaries of females caught at the different sampling sites are difficult to explain since oogenesis is highly dependent on local environmental conditions and is therefore not perfectly synchronized among individuals from the different stations. However, females from the BKME and PCB contaminated sites displayed a significantly higher proportion of preovulatory atretic follicles than fish caught at reference site 2 . The effects of such contaminants on the ovarian development and integrity in fish have been previously reported (Adams et al., 1992b; Hugla, 1994). Furthermore, females from the pesticide contaminated site displayed a proportion of preovulatory atretic follicles significantly higher than fish from both reference sites, suggesting that the ovarian integrity in chubs from the pesticide contaminated site was particularly affected. An increased level of atretic oocytes has also been observed in female goldfish after three weeks exposure to atrazine (Spanò et al., 2004). Moreover, histological effects on ovaries and inhibited ovarian growth have been reported in freshwater catfish ( $H$. fossilis) exposed to hexachlorocyclohexane (Singh et al., 1993). This suggests a toxic effect of such pesticides on ovarian development in fish.

\subsection{Population analysis}

Chub populations from both reference sites were well-balanced, showing a prevalent cohort of one-year old fish indicating a good recruitment, and older individuals belonging to various size classes. In the PCB contaminated site, the total number of individuals was very low and almost all of them were juveniles. This could be related to the acute contamination by aluminium that had impacted this river a few months before sampling. Young chubs would have been less affected than adults, due to the habitat difference between juveniles and older individuals. Recolonization may also have contributed with juvenile fish from upstream spawning areas, since chub fry is known to passively scatter after the yolk vesicle resorption (Keith and Allardi, 2001). On the other hand, chub populations from the BKME and pesticide contaminated sites were visibly unbalanced, with clearly under-represented young cohorts, suggesting a deterioration of recruitment. Such an abnormal population structure has also been reported in redbreast sunfish (Lepomis auritus) exposed to BKME (Adams et al., 1992b). In this latter study, both alterations of the reproductive function in spawning adults and a higher sensitivity of early lifestages to contaminations were considered as responsible for the skewed size distribution. However, in our study, other alterations could be responsible for the apparent recruitment hiatus. Disturbances in fish populations have been noted in stations where habitat structure was poor and monotonous (Faller et al., 2003) or where interruptions of the longitudinal integrity were reported (Siligato and Böhmer, 2001).

\subsection{Fish community assessment}

As reported in several studies (Adams et al., 1992b, 2000; Porter and Janz, 2003), high IBI scores were 
recorded in the three contaminated sites. The main trend observed in those sites was a shift from intolerant species to more tolerant ones revealed by the "percentage of intolerant individuals" metric. Similar modifications have also been reported in a small urban stream system in Germany (Siligato and Böhmer, 2002). In BKME and PCB contaminated sites, low ratios of bullhead/bullhead + loach were noted as a consequence of the decline of bullhead, an intolerant benthic species replaced by the more tolerant benthic stone loach. In the PCB contaminated site, reduced fish diversity was also noted, most notably among the benthic guild. This should be related to the particular behaviour of weakly hydrosoluble pollutants such as PCB which often adsorb on fine particles and concentrate in sediments.

Moreover, although grayling (Thymallus thymallus) was present at this site, its population was heavily unbalanced since all individuals were adult fish that had roughly the same length $(257 \pm 11 \mathrm{~mm})$, causing a high individual score for the "presence of fry, juveniles and adults in the dominant species among the intolerant ones" metric. Finally, in the pesticide contaminated site, the community was dominated by roach, an ubiquist and highly tolerant species, explaining the high metric scores in "percentage of intolerant individuals" and "percentage of individuals as specialized spawners". However, it must be mentioned that IBI scores do not only measure water quality alterations, but also evaluate habitat modifications, making this measurement an integrator index for which the determination of exact mechanisms responsible for the observed changes is rather difficult.

\section{Conclusion}

The responses observed at different levels of organization in fish caught at the three contaminated stations are shown in Table 7. In summary, there were similarities in the trends of the status of fish sampled in the different sites based on the multi-level approach. The exposure to xenobiotic compounds was revealed by a high hepatic EROD activity and similar ALP values in both sexes. Other biomarkers (GST activity, HSP70 levels, plasma sex steroid concentrations) failed to discriminate between fish caught in the different stations. However, although they are very sensitive and represent early signals of environmental contamination (Lam and Gray, 2003; van der Oost et al., 2003), biochemical responses often are of little relevance to higher levels of organization (Triebskorn et al., 2001). Moreover, biomarker-type responses in the field can be masked by several modulating factors such as contaminant antagonists or environmental parameters (Amiard et al., 1998; van der Oost et al., 2003). This was particularly the case of endocrine parameters since the hormonal status of fish is highly changeable during the reproductive period, depending on the environmental conditions of the station.

On the other hand, population and community parameters are more ecologically relevant and reflect integrated conditions over a long time period. In this study, unbalanced chub populations and altered fish communities were observed in the contaminated sites. However, higher level approaches often lack sensitivity and take into account a wide range of environmental factors other than pollution (Attrill and Depledge, 1997) since other environmental factors like habitat structure (Siligato and Böhmer, 2002; Faller et al., 2003), specific pathologies or high predation intensity (Fischnetz, 2004) are likely to influence the population and community constitution. Given the fundamental limitations of every single-level approach and the tremendous complexity of ecological systems, the only way to obtain a realistic view of the ecological health of an ecosystem is to consider a simultaneous use of several indicators at various levels of biological organization (Lagadic et al., 1997). Therefore, interdisciplinary studies like the VALIMAR (Triebskorn et

Table 7

Responses at different levels of biological organization of fish from the three contaminated sampling sites in regard with values noted in at least one of the two reference stations

\begin{tabular}{llll}
\hline & BKME & PCB & Pesticides \\
\hline $\begin{array}{l}\text { Fish community assessment } \\
\text { Chub population analysis }\end{array}$ & $\begin{array}{l}\text { High IBI score } \\
\text { Unbalanced population } \\
\text { with few juveniles } \\
\text { Reproductive parameters }\end{array}$ & $\begin{array}{l}\text { High IBI score } \\
\text { Disrupted population with } \\
\text { quite exclusively juveniles } \\
\text { (High variability) }\end{array}$ & $\begin{array}{l}\text { High IBI score } \\
\text { Unbalanced population with } \\
\text { few juveniles } \\
\text { (Himilar ALP values in males } \\
\text { Biochecmical measurements }\end{array}$ \\
& $\begin{array}{l}\text { High hepatic EROD activity } \\
\text { in female chubs }\end{array}$ & $\begin{array}{l}\text { High hepatid EROD activity } \\
\text { in female chubs }\end{array}$ & $\begin{array}{l}\text { High proportion of atretic follicles } \\
\text { High hepatic EROD activity in } \\
\text { female and male chubs }\end{array}$ \\
\hline
\end{tabular}


al., 2001) and FISCHNETZ (Fischnetz, 2004) projects must be encouraged. Such multi-level approaches are particularly important when investigating the effects of multiple stressors on wild species because it is generally not known which stress response(s) might be affected.

\section{Acknowledgements}

The authors are grateful to M.-C. Forget and M. Albert, as well as A. Evrard from URBO for their invaluable help in biochemical analysis and fish sampling, respectively. Thanks are also due to the Laboratory of Histology and Embryology of FUNDP for access to histological equipment and to M. Louvet and C. Dykmans from LEAE, for their help during the chemical analysis. O. Carabin (ULg), B. Moreau and T. Demol (Centre de Recherche de la Nature, de la Forêt et $\mathrm{du}$ Bois (Belgium) are acknowledged for their assistance during the fish sampling. This study was performed with the financial support of the National Funds for Scientific Research (FRFC contract 2.4544.02.F).

\section{References}

Adams SM, Crumby WD, Greeley Jr MS, Ryon MG, Schilling EM. Relationships between physiological and fish population responses in a contaminated stream. Environ Toxicol Chem 1992a; 11:1549-57.

Adams SM, Crumby WD, Greeley Jr MS, Shugart LR, Saylor CF. Responses of fish populations and communities to pulp mill effluents: a holistic assessment. Ecotoxicol Environ Saf 1992b; 24:347-60.

Adams SM, Greeley MS, Ryon MG. Evaluating effects of contaminants on fish health at multiple levels of biological organization: extrapolating from lower to higher levels. Hum Ecol Risk Assess 2000;6:15-27.

Addison RF, Zinck ME, Willis DE, Wrench JJ. Induction of hepatic mixed function oxidase activity in trout (Salvelinus fontinalis) by Aroclor 1254 and some aromatic hydrocarbon PCB replacements. Toxicol Appl Pharmacol 1982;63:166-72.

Amiard J-C, Caquet T, Lagadic L. Les biomarqueurs parmi les méthodes d'évaluation de la qualité de l'environnement. In: Lagadic L, Caquet T, Amiard J-C, Ramade F, editors. Utilisation des biomarqueurs pour la surveillance de la qualité de l'environnement. Paris: Tec \& Doc; 1998. p. XXI-XXXI.

Arukwe A. Cellular and molecular responses to endocrine modulators and the impact on fish reproduction. Mar Pollut Bull 2001; 42:643-55.

Arukwe A, Celius T, Walther BT, Goksøyr A. Effects of xenoestrogen treatment on zona radiata protein and vitellogenin expression in Atlantic salmon (Salmo salar). Aquat Toxicol 2000;49:159-70.

Attrill M, Depledge MH. Community and population indicators of ecosystem health: targetting links between levels of biological organization. Aquat Toxicol 1997;38:183-97.
Bagchi D, Bhattacharya G, Stohs SJ. In vitro and in vivo induction of heat shock (stress) protein (Hsp) gene expression by selected pesticides. Toxicology 1996;112:57-68

Bateman KS, Stentiford GD, Feist SW. A ranking system for the evaluation of intersex condition in European flounder (Platichtys flesus). Environ Toxicol Chem 2004;23:2831-6.

Behrens A, Segner H. Hepatic biotransformation enzymes of fish exposed to non-point source pollution in small streams. J Aquat Ecosyst Stress Recovery 2001;8:281-97.

Bernet D, Schmidt H, Meier W, Burkhardt-Holm P, Wahli T. Histopathology in fish: proposal for a method to assess aquatic pollution. J Fish Dis 1999;22:25-34.

Bernet D, Schmidt H, Wahli T, Burkhardt-Holm P. Effects of waste water on fish health: an integrated approach to biomarker responses in brown trout (Salmo trutta L.). J Aquat Ecosyst Stress Recovery 2000;8:143-51.

Bosveld ATC, de Bie PAF, van den Brink NW, Jongepier H, Klomp $\mathrm{AV}$. In vitro EROD induction equivalency factors for the $10 \mathrm{PAHs}$ generally monitored in risk assessment studies in The Netherlands. Chemosphere 2002;49:75-83.

Bozcaarmutlu A, Arinç E. Inhibitory effects of divalent metal ions on liver microsomal 7-ethoxyresorufin $O$-deethylase (EROD) activity of leaping mullet. Mar Environ Res 2004;58:521-4.

Cellule Etat de l'Environnement Wallon. Tableau de Bord de l'environnement wallon, Ed. MRW-DGRNE; 2003. 142 pp.

Coakley J, Hodson PV, van Heiningen A, Cross T. MFO induction in fish by filtrates from chlorine dioxide bleaching of wood pulp. Water Res 2001;35:921-8

Council of European Communities. Directive 2000/60/EC of the European Parliament and of the Council of 23 October 2000 establishing a framework for community action in the field of water policy. Official J Eur Communities, vol. L327 43; 2000. p. 1-72.

Debier C, Pomeroy PP, Dupont C, Joiris C, Comblin V, Le Boulengé E, et al. Quantitative dynamics of PCB transfer from mother to pup during lactation in UK grey seals Halichoerus grypus. Mar Ecol Prog Ser 2003;247:237-48.

Devaux A, Flammarion P, Bernardon V, Garric J, Monod G. Monitoring of the chemical pollution of the river Rhône through measurement of DNA damage and cytochrome P4501A induction in chub (Leuciscus cephalus). Mar Environ Res 1998;46:257-62.

Dhainaut A, Bonaly J, Barque J-P, Minier C, Caquet T. Protéines de choc thermique et résistance multixénobiotique. In: Lagadic $\mathrm{L}$, Caquet T, Amiard J-C, Ramade F, editors. Biomarqueurs en écotoxicologie, aspects fondamentaux. Paris: Masson; 1997. p. 67-95.

Eder K, Leutenegger C, Wilson B, Werner I. Molecular and cellular biomarker responses to pesticide exposure in juvenile chinook salmon (Oncorhynchus tshawytscha). Mar Environ Res 2004; 58:809-13.

Egaas E, Skaare JU, Svendsen NO, Sandvink M, Falls JG, Dauterman WC, et al. A comparative study of effects of atrazine on xenobiotic metabolizing enzymes in fish and insect, and of the in vitro phase II atrazine metabolism in some fish, insects, mammals and one plant species. Comp Biochem Physiol C 1993;106:141-9.

Faller P, Kobler B, Peter A, Sumpter JP, Burkhardt-Holm P. Stress status of gudgeon (Gobio gobio) from rivers in Switzerland with and without input of sewage treatment plant effluent. Environ Toxicol Chem 2003;22:2063-72.

Feder ME, Hofmann GE. Heat-shock proteins, molecular chaperones, and the stress response: evolutionary and ecological physiology. Annu Rev Physiol 1999;61:243-82.

Fischnetz. Sur la trace du déclin piscicole. Rapport final. Dübendorf, Bern: EAWAG/OFEFP; 2004. 198 pp. 
Flammarion P, Migeon B, Garric J. Statistical analysis of cyprinid ethoxyresorufin-Odeethylase data in a large french watershed. Ecotoxicol Environ Saf 1998a;40:144-53.

Flammarion P, Migeon B, Urios S, Morfin P, Garric J. Effect of methidathion on the cytochrome P-450 1A in the cyprinid fish gudgeon (Gobio gobio). Aquat Toxicol 1998b;42:93-102.

Flammarion P, Noury P, Garric J. The measurement of cholinesterase activities as a biomarker in chub (Leuciscus cephalus): the fish length should not be ignored. Environ Pollut 2002;120:325-30.

Fostier A, Jalabert B. Steroidogenesis in rainbow trout (Salmo gairdneri) at various preovulatory stages: changes in plasma hormone levels and in vivo and in vitro responses of the ovary to salmon gonadotropin. Fish Physiol Biochem 1986;2:87-99.

Fredrich F, Ohmann S, Curio B, Kirschbaum F. Spawning migrations of the chub in the River Spree, Germany. J Fish Biol 2003; 63:710-23.

Gernöfer M, Pawert M, Schramm M, Müller E, Triebskorn R. Ultrastructural biomarkers as tool to characterize the health status of fish in contaminated streams. J Aquat Ecosyst Stress Recovery 2001;8:241-60.

Habig WH, Pabst MJ, Jakoby WB. Glutathione $S$-transferase, the first enzymatic step in mercapturic acid formation. J Biol Chem 1974;249:7130-9.

Hahn ME. Biomarkers and bioassays for detecting dioxin-like compounds in the marine environment. Sci Total Environ 2002; 289:49-69.

Hanioka N, Jinno H, Tanaka-Kagawa T, Nishimura T, Ando M. Changes in rat liver cytochrome $\mathrm{P} 450$ enzymes by atrazine and simazine treatment. Xenobiotica 1998;28:683-98.

Hecker, M. Natural variability of enocrine functions and their modulation by anthropogenic influences: investigations of the bream (Abramis brama [L.]) along the Elbe river, and a reference site. Ph.D. thesis at the University of Hamburg, Germany (English Abstract). In Berichte aus dem ZMK Reihe E, 16; 2001. 157 pp.

Huet M. Aperçu des relations entre la pente et les populations piscicoles des eaux courantes. Rev Suisse Hydrobiol 1949; 11:332-51.

Hughes RM, Oberdorff T. Application of IBI concepts and metrics to waters outside the United States and Canada. In: Simon TP, editor. Assessing the sustainability and biological integrity of water resources using fish communities. Boca Raton, FL USA: Lewis press; 1998. p. 79-83.

Hugla, J-L. Dynamique de transfert des biphényles polychlorés (PCB) chez le barbeau (Barbus barbus) et analyse des risques écotoxicologiques pour les populations naturelles: incidence sur la reproduction et sur les fonctions hépatiques. Thèse de doctorat, Laboratoire de morphologie, systématique et écologie animales, Université de Liège; 1994. 197 pp.

Hugla J-L, Thomé J-P. Effects of polychlorinated biphenyls on liver ultrastructure, hepatic monooxygenases, and reproductive success in the barbel. Ecotoxicol Environ Saf 1999;42:265-73.

Hugla J-L, Philippart J-C, Kremers P, Goffinet G, Thomé J-P. PCB contamination of the common barbel, Barbus barbus (Pisces, Cyprinidae), in the river Meuse in relation to hepatic monooxygenase activity and ultrastructural liver changes. Neth J Aquat Ecol 1995;29:135-45.

Illies J. Limnofauna Europaea. A check-list of the animal inhabiting European inland waters, with an account of their distribution and ecology. 2nd ed. Stuttgart: Gustav Fischer Verlag; 1978. 241 pp.
Janssen PAH, Lambert JGD, Vethaak AD, Goos HJTh. Environmental pollution caused elevated concentrations of oestradiol and vitellogenin in the female flounder, Platichtys flesus (L.). Aquat Toxicol 1997;39:195-214.

Janz DM, McMaster ME, Munkittrick KR, Van Der Kraak G. Elevated ovarian follicular apoptosis and heat shock protein-70 expression in white sucker exposed to bleached kraft pulp mill effluent. Toxicol Appl Pharmacol 1997;147:391-8.

Janz D, McMaster M, Weber L, Munkittrick K, Van der Kraak G. Recovery of ovary size, follicle cell apoptosis and HSP70 expression in fish exposed to bleached kraft mill effluent. Can J Fish Aquat Sci 2001;58:620-5.

Jobling S, Nolan M, Tyler CR, Brighty G, Sumpter JP. Widespread sexual disruption in wild fish. Environ Sci Technol 1998; 32:2498-506.

Karr JR, Fausch KD, Angermeier PL, Yant PR, Schlosser IJ. Assessing biological integrity in running waters: a method and its rationale. Ill Nat Hist Surv Spec Publ, vol. 5; 1986. Urbana, 28 pp.

Keith P, Allardi J. Atlas des poissons d'eau douce de France. Patrimoines Naturels, vol. 47. Paris; 2001. 387 pp.

Kestemont P. Etude du cycle reproducteur du goujon, Gobio gobio L: 1. Variations saisonnières dans l'histologie de l'ovaire. J Appl Ichtyol 1987;4:145-57.

Kestemont P, Philippart J-C. Considérations sur la croissance ovocytaire chez les poissons à ovogenèse synchrone et asynchrone. Belg J Zool 1991;121:87-98.

Kestemont P, Didier J, Depiereux E, Micha J-C. Selecting ichtyological metrics to assess river basin ecological quality. Arch Hydrobiol Suppl 2000;121:321-48.

Kime DE. Endocrine disruption in fish. MA: Kluwer Academic Publishers; 1998. 396 pp.

Kime DE, Nash JP, Scott AP. Vitellogenesis as a biomarker of reproductive disruption by xenobiotics. Aquaculture 1999; 177:345-52.

Kosmala, A. Evaluation écotoxicologique de l'impact des effluents de stations d'épuration sur les cours d'eau: intérêt d'une approche intégrée. Thèse de doctorat, UFR Sciences Fondamentales et Appliquées, Université de Metz; 1998. 183 pp.

Kovacs T, Martel P, Voss R. Assessing the biological status of fish in a river receiving pulp and paper mill effluents. Environ Pollut 2002; 118:123-40.

Lagadic L, Caquet T, Amiard J-C. Introduction: biomarqueurs en écotoxicologie, principes et définitions. In: Lagadic L, Caquet T, Amiard J-C, Ramade F, editors. Biomarqueurs en écotoxicologie, aspects fondamentaux. Paris: Masson; 1997. p. 1-10.

Lam PKS, Gray JS. The use of biomarkers in environmental monitoring programmes. Mar Polut Bull 2003;46:182-6.

Langeron P. Précis de microscopie technique - expérimentation diagnostic. Paris: Masson; 1942. 1339 pp.

Lawrence AJ, Arukwe A, Moore M, Sayer M, Thain J. Molecular/ cellular processes and the physiological responses to pollution. In: Lawrence AJ, Hemingway KL, editors. Effects of pollution on fish, molecular effects and population responses. Blackwell Publishing; 2003. p. 83-133.

Lowry OH, Rosebrough NJ, Farr AL, Randall RJ. Protein measurement with the Folin phenol reagent. J Biol Chem 1951; 193:265-75.

Mandiki SNM, Babiak I, Bopopi JM, Leprieur F, Kestemont P. Effects of sex steroids and their inhibitors on endocrine parameters and gender growth differences in Eurasian perch (Perca fluviatilis) juveniles. Steroids 2005;70:85-94. 
Masfaraud J-F, Monod G, Devaux A. Use of the fish cytochrome P-450 dependent 7- ethoxyresorufin O-deethylase activity as a biochemical indicator of water pollution. Study of the liver and the kidney of male and female nase (Chodrostoma nasus) from the river Rhône. Sci Total Environ 1990;9798:729-38.

McMaster ME, Van der Kraak GJ, Munkittrick KR. Exposure to bleached kraft pulp mill effluent reduces the steroid biosynthetic capacity of white sucker ovarian follicles. Comp Biochem Physiol C 1995;112:169-78.

Monod G. L'induction du cythochrome P4501A. In: Lagadic L, Caquet T, Amiard J-C, Ramade F, editors. Biomarqueurs en écotoxicologie, aspects fondamentaux. Paris: Masson; 1997. p. 33-51.

Monteiro P, Reis-Henriques M, Coimbra J. Plasma steroid levels in female flounder (Platichtys flesus) after chronic diatery exposure to single polycyclic aromatic hydrocarbons. Mar Environ Res 2000;49:453-67.

MRW_DGRNE et coll. Etat de l'Environnement Wallon; 2000. $420 \mathrm{pp}$.

Nunn AD, Cowx IG, Harvey JP. Recruitment pattern of six species of cyprinid fishes in the lower River Trent, England. Ecol Freshw Fish 2002;11:74-84.

O'Hare DB, Siddall R, Robotham PWJ, Gill RA. Influence of oestradiol on induction of EROD activity in roach (Rutilus rutilus L.). Chemosphere 1995;30:1423-8.

Parmar D, Yadav S, Dayal M, Johri A, Dhawan A, Seth PK. Effect of lindane on hepatic and brain cytochrome P450s and influence of P450 modulation in lindane induced neurotoxicity. Food Chem Toxicol 2003;41:1077-87.

Pickering AD, Pottinger TG. Biochemical effects of stress. Biochem Mol Biol Fishes 1995;5:349-71.

Poncin P. Le contrôle environnemental et hormonal de la reproduction $\mathrm{du}$ barbeau, Barbus barbus (L.), et du chevaine, Leuciscus cephalus (L.) (Pisces Cyprinidae), en captivité. Cah Ethol Appl 1988;8:173-330.

Porter CM, Janz D. Treated municipal sewage discharge affects multiple levels of biological organization in fish. Ecotoxicol Environ Saf 2003;54:199-206.

Power M. Assessing the effects of environmental stressors on fish populations. Aquat Toxicol 1997;39:151-69.

Pyza E, Mak P, Kramarz P, Laskowski R. Heat shock proteins (HSP70) as biomarkers in ecotoxicological studies. Ecotoxicol Environ Saf 1997;38:244-51.

Rinchard J, Kestemont P. Comparative study of reproductive biology in single- and multiple spawner cyprinid fish: I. Morphological and histological features. J Fish Biol 1996;49:883-94.

Rinchard J, Poncin P, Kestemont P. Croissance ovocytaire et régulation stéroïdienne chez les poissons à pontes unique et multiples: une revue. Ann Limnol 1998;34:211-25.

Sepúlveda MS, Johnson WE, Higman JC, Denslow ND, Schoeb TR, Gross TS. An evaluation of biomarkers of reproductive function and potential contaminant effect in Florida largemouth bass (Micropterus salmoides floridanus) sampled from the St. Johns river. Sci Total Environ 2002;289:133-44.

Siligato S, Böhmer J. Using indicators of fish health at multiple levels of biological organization to assess effects of stream pollution in southwest Germany. J Aquat Ecosyst Stress Recovery 2001; 8:371-86.

Siligato S, Böhmer J. Evaluation of biological integrity of small urban stream system by investigating longitudinal variability of the fish assemblage. Chemosphere 2002;47:777-88.
Singh PB, Canario AV. Reproductive endocrine disruption in the freshwater catfish, Heteropneustes fossilis, in response to the pesticide gamma-hexachlorocyclohexane. Ecotoxicol Environ Saf 2004;58:77-83.

Singh PB, Kime DE, Singh TP. Modulatory actions of Mystus gonadotropin on g-BHCinduced histological changes, cholesterol and sex steroid levels in Heteropneustes fossilis. Ecotoxicol Environ Saf 1993;25:141-53.

Soimasuo R, Jokinen I, Kukkonen J, Petänen T, Ristola T, Oikari A. Biomarker responses along a pollution gradient: effects of pulp and paper mill effluents on caged whitefish. Aquat Toxicol 1995;31: $329-45$.

Solé M, Porte C, Barcelo D. Analysis of the estrogen activity of sewage treatment works and receiving waters using vitellogenin induction in fish as a biomarker. Trends Anal Chem 2001; 20:518-25.

Spanò L, Tyler C, van Aerle R, Devos P, Mandiki SNM, Silvestre F, et al. Effects of atrazine on sex steroid dynamics, plasma vitellogenin concentration and gonad development in adult goldfish Carassius auratus L. Aquat Toxicol 2004;66:369-79.

Sumpter JP. Xenoendocrine disrupters-environmental impacts. Toxicol Lett 1998;102-103:337-42.

Thomé J-P, Hugla J-L, Adam C, Goffinet G. Incidence d'une contamination chronique par les PCBs sur la morphologie et l'ultrastructure du foie chez le barbeau fluviatile (Barbus barbus). Cah Ethol 1993;13:151-4.

Triebskorn R, Böhmer J, Braunbeck T, Honnen W, Köhler H-R, Lehmann $\mathrm{R}$, et al. The project VALIMAR (VALIdation of bioMARkers for the assessment of small stream pollution): objectives, experimental design, summary of results, and recommandations for the application of biomarkers in risk assessment. J Aquat Ecosyst Stress Recovery 2001;8:161-78.

van der Oost R, Lopes S, Komen H, Satumalay K, Van den Bos R, Heida $\mathrm{H}$, et al. Assessment of environmental quality and inland water pollution using biomarker responses in caged carp (Cyprinus carpio): use of bioactivation ratio as a biotransformation index (BTI). Mar Environ Res 1998;46:315-9.

van der Oost R, Beyer J, Vermeulen NPE. Fish bioaccumulation and biomarkers in environmental risk assessment: a review. Environ Toxicol Pharmacol 2003;13:57-149.

Verslycke T, Vandenbergh GF, Versonnen B, Arijs K, Janssen CR. Induction of vitellogenesis in $17 \alpha$-ethinylestradiol-exposed rainbow trout (Oncorhynchus mykiss): a method comparison. Comp Biochem Physiol C 2002;132:483-92.

Viarengo A, Bettella E, Fabbri R, Burlando B, Lafaurie M. Heavy metal inhibition of EROD activity in liver microsomes from the bass Dicentrarchus labrax exposed to organic xenobiotics: Role of GSH in the reduction of heavy metal effects. Mar Environ Res 1997;44:1-11.

Vijayan MM, Pereira C, Kruzynski G, Iwama GK. Sublethal concentrations of contaminant induce the expression of hepatic heat shock protein 70 in two salmonids. Aquat Toxicol 1998; 40:101-8.

Vindimian E, Namour P, Migeon B, Garric J. In situ pollution induced cytochrome P450 activity of freshwater fish: barbel (Barbus barbus), chub (Leuciscus cephalus) and nase (Chondrostoma nasus). Aquat Toxicol 1991;21:255-66.

Vodicnik MJ, Lech JJ. The effect of sex steroids and pregnenolone$16 \alpha$-carbonitrile on the hepatic microsomal monooxygenase system of rainbow trout (Salmo gairdneri). J Steroid Biochem 1983;18:323-8. 
Wahli, T, Meier, W, Segner, H, Burkhardt-Holm, P. Immunohistochemical detection of vitellogenin in male brown trout of Swiss rivers. Histochem J; 30:753-758.

Wallace RA, Jared DW. Studies on amphibian yolk. VII. Serum phosphoprotein synthesis by vitellogenic females and oestrogentreated males. Can J Biochem 1968;46:953-9.

Weber L, Diamond S, Bandiera S, Janz D. Expression of HSP70 and CYP1A protein in ovary and liver of juvenile rainbow trout exposed to $\beta$-naphtoflavone. Comp Biochem Physiol C 2002;131:387-94.

Wester PW, Canton JH. Histopathological study of Oryzias latipes (medaka) after long-term $\beta$-hexachlorocyclohexane exposure. Aquat Toxicol 1986;9:21-45. 